\title{
SOCRATES ON LIFE AND DEATH (PLATO, APOLOGY $\left.40 \mathrm{C}_{5}-4 \mathrm{IC}_{7}\right)^{\star}$
}

In a familiar passage at the end of Plato's Apology, Socrates offers an account of what he believes will happen to us when we die. As in the Phaedo, it is his impending death that prompts Socrates to speculate about the nature of the afterlife: as soon as his verdict is announced, Socrates turns to the jury to gloss on his sentencing. It was unprecedented, as far as we know, for a defendant in the Athenian court to end his trial by addressing the members of the jury, but the Apology has Socrates doing just that. ${ }^{1}$ While his defence in the Apology was already audacious, Socrates' closing speech appears even more provocative. Among other things, he declares that he has no reason to fear death, but that, on the contrary, the death penalty he received only moments before may well be considered a blessing. Socrates supports this claim with an argument in the form of a constructive dilemma: either death involves the cessation of consciousness, in which case our afterlife existence will resemble a single night of dreamless sleep, or after our death we will go to a place where all the dead are ruled over by just judges. Since either scenario constitutes a good state, death should be considered something good $\left(40 \mathrm{C}_{5}-4 \mathrm{IC}_{7}\right)$. This article will examine Socrates' argument in detail and discuss a number of salient problems that arise from it. Commentators have typically attempted to tackle the interpretative problems one by one, but I shall argue that they resist satisfactory resolution and instead alert us to an ironic reading of this passage.

I would like to thank David Sedley, Chris Bobonich, René Brouwer and the two anonymous readers of the Cambridge Classical Journal for their insightful comments on earlier versions of this article; discussions on an early draft with Rachana Kamtekar and David Johnson helped shape my view on this passage. Critical audiences in Flagstaff and Amsterdam provided helpful discussion.

${ }^{2}$ See De Strycker and Slings (1994) 201-4 for a discussion of the practical problems such a speech would have posed in practice; cf. Burnet (I924) I6I-2. Yet it is remarkable that also Xenophon shows Socrates addressing the jury following his conviction (Xen., Ap. 24-26). However, I will not be concerned with the response of the historical Socrates to his verdict, but only with the arguments presented by Plato's literary character Socrates in the Apology. 
Before we move to the argument itself and the concerns it raises, let me make a few preliminary remarks on its context. The constructive dilemma establishing that death is something good is part of Socrates' speech to the jury members who voted for his acquittal $(38 \mathrm{EI}-42 \mathrm{~A} 4)$. Socrates begins by giving these 'true jurors', whom he calls his 'friends', an argument for why his death is not the worst that could have happened to him based on the silence of his divine sign. He argues that the absence of the divine sign from the moment he set out to the courthouse until the end of his defence speech means that he can be reassured that he took the right course of action all along. He adds that this silence perhaps even gives him reason to believe that the result of his speech - the death sentence and ultimately death itself - is not bad for him. ${ }^{2}$ In any case, it is not the 'worst of evils': since in the past his divine sign intervened even in cases where a minor evil would have resulted from his actions, he can safely assume that it would have intervened now too if he were to face what is believed to be the worst of evils in the form of his death sentence $\left(4 \mathrm{OA}_{2}-\mathrm{C}_{4}\right)$. Socrates then introduces the constructive dilemma as (further) evidence for the claim that death is something good.

The most conspicuous concern raised by the argument in favour of death as something good is that it is blatantly unsound. This is how Socrates presents the argument:

Let us consider also in the following way that there is much hope that being dead is something good. For to be dead ( $\tau$ ò $\tau \varepsilon \theta v \alpha$ ó $v$ ) is one of two things: either it is like being nothing and the dead person does not

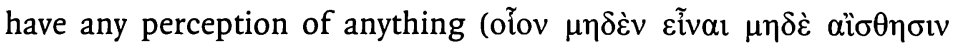

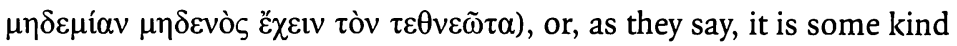
of change, namely relocation, of the soul from here to another place. And if it is indeed a complete absence of perception, like the sleep of someone who does not even dream at all, death would be a remarkable

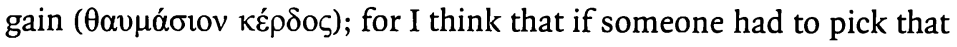

\footnotetext{
2 Note a subtle change in Socrates' analysis of the reason for (non-)intervention by his divine sign: he first claims that his divine sign used to oppose him 'if I was about to do something that was not right' ( $\varepsilon i \mathrm{i} \tau$

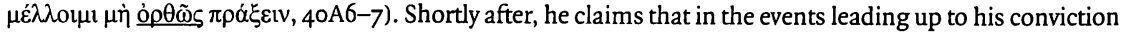

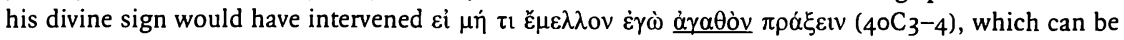
understood not just as 'if I was not about to do something right', but also as 'if I was not about to incur something good'.
} 
night during which he slept so soundly that he did not dream, and then put all the other nights and days of his life next to that night, and, having looked at them, had to say how many nights and days he had had that were better than that night, I think that not just a private citizen, but also the Great King himself would find them easy to count compared to the other days and nights. If death, then, is like that, I declare it a gain ( $\left.\kappa \dot{\varepsilon} \rho \delta 0_{5}\right)$; for in that case the whole of time seems to be no more than a single night. And if, on the other hand, death is like going abroad from here to another place, and what they say is true, that everyone who died is there, what greater good than that could there be, jurymen? For if, having escaped from those people there who claim to be judges ( $\delta \kappa \alpha \sigma \tau \tilde{\omega} v)$, and having arrived in Hades, one finds true judges ( $\delta \kappa \alpha \sigma \tau \dot{\alpha} \varsigma)$, just those who are said to sit in judgement there, Minos, Rhadamantys, Aeacus, Triptolemos and all the other half-gods who were just during their lives, would that be a bad way to go abroad $(\dot{\alpha} \pi \circ \delta \eta \mu i \alpha)$ ?3 How much would one of you give to converse with Orpheus, Musaeus, Hesiod and Homer? I am willing to die many times

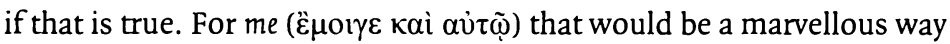
to spend my time $(\theta \alpha u \mu \alpha \sigma \tau \dot{\eta} \dot{\eta} \delta 1 \alpha \tau \rho \imath \beta \dot{\eta})$ there, whenever I met Palamedes and Ajax, the son of Telamon, and anyone else of long ago who died through an unjust verdict to compare my experiences with theirs (which I think would not be unpleasant); most importantly, I would spend my time scrutinizing and examining people there, as I do here, to find out which of them is wise, and which of them thinks he is wise but is not. How much would one not give, gentlemen of the jury, to examine the man who lead the expedition against Troy, or Odysseus, or Sisyphus, or the countless others one could mention, men and women, whom it would be an inconceivable happiness (á $\mu$ í $\chi \alpha v o v$

${ }^{3}$ The same term, $\delta$ ika $\sigma \tau \alpha$, is used both for the members of the Athenian jury and for the underworld judges who traditionally settle disputes between underworld inhabitants (on the traditional role of the underworld judges, see De Strycker and Slings (1994) 227-8). These underworld judges are introduced by Plato in the Gorgias as judging all souls entering the underworld. The Apology, not mentioning a universal judgement of underworld entrants, does not explicitly attribute a similar role to the three underworld judges. On the contrary, Socrates' statement that, unlike in Athens, in the underworld he will not be put to death for examining people suggests that it is in their traditional role of settling disputes among underworld inhabitants that the underworld judges would issue a different verdict from the Athenian jury in any trial against Socrates. 
$\varepsilon v \delta \delta \alpha \mu o v i ́ \alpha \varsigma)$ to talk to and keep company with and examine. At any rate they surely do not put one to death for this. And also in other respects the people there are happier than the people here, and they are immortal for the rest of time as well, if indeed what they say is true. $\left(4 \mathrm{OC}_{5}-4 \mathrm{IC}_{7}\right)$

Socrates' argument runs as follows: either death entails the cessation of our conscious existence or it entails a departure to some other place. If death means such a complete lack of perception that it resembles a 'dreamless sleep', death would be a 'surprising gain', since even the traditional paragon of happiness, the Great King, would be able to find few days and nights of his life better than a night of dreamless sleep. If, on the other hand, death involves the transmigration of the dead to some other place where all the deceased reside, death would be an even greater blessing. For there is no greater good than to be able to keep the company of the illustrious dead, such as the great poets and their heroic subjects, to examine them, and to face no consequences for doing so. Therefore, on both possible afterlife accounts, death is something good.

The first striking flaw in the argument is the incompleteness of the set of afterlife scenarios. ${ }^{4}$ Socrates suggests that they exhaust the range of options. But although the pair of alternatives as initially presented - 'death is like being nothing or is some kind of change or relocation' - can be considered mutually exhaustive if we make some minor allowances, the way in which Socrates subsequently develops these alternatives certainly does not encompass all possible or even all relevant views. ${ }^{5}$ For example,

\footnotetext{
${ }^{4}$ A host of commentators have highlighted this point: see Armleder (I966) 46; Roochnik (I985) 213-4; De Strycker and Slings (1994) 218-26; Stokes (1997) I89; McPherran (I996) 258-9; Rudebusch (I999) 67-8. Brickhouse and Smith (1989) 257 argue that 'nothing [Socrates] says should encourage us to assume that the two alternatives he outlines exhaust, in his view, all the possibilities'. Brad Inwood made the insightful observation that with this 'false dilemma' Socrates, who after all has just delivered a forensic speech, is employing a device common in orators' speeches.

5 Although the first scenario does not state that death is non-existence, only that it is like non-existence, the upshot of this scenario would not meaningfully differ from death as the definitive cessation of all mental and physical activity. Later, (ps.-)Plutarch attributes not two, but three options to Socrates: 'Death resembles either a very deep sleep or a long and protracted journey, or, thirdly, a sort of destruction and

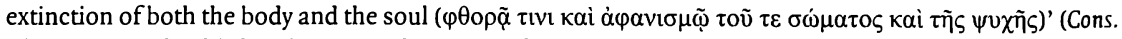
ad Ap. I07D). The third option, tagged on somewhat awkwardly to the first two, need not be an expansion of the constructive dilemma in the Apology, as Warren suggests in his (2004) 73. A perhaps more likely origin for this option would be Phd. $\operatorname{I0}_{7} \mathrm{C}_{5}-8$, where Socrates entertains the hypothesis that 'if death were a release from everything ( $\tau 0 \tilde{v} \pi \alpha \nu \tau$ tò $\dot{\alpha} \pi \alpha \lambda \lambda \alpha \gamma \eta$ ), then for the dead who are wicked it would be a godsend to be released from their bodies and at the same time from their wickedness together with their soul.' Interestingly, in the pseudo-Platonic Axiochus, predating (ps.-)Plutarch's Consolation, but part of the same genre of consolation literature, Socrates comforts Axiochus with a series of Epicurean arguments asserting that after death we no longer exist and lack all perception; see ps.-Plat., Ax. 365 Di-E2, 369B5-370Br.
} 
Socrates does not consider the commonly held belief that death, instead of eradicating our experiences altogether, reduces us to a shadowlike existence that limits our experiences so drastically that Homer's Achilles prefers to live as a day-labourer on earth over being a ruler among the dead. ${ }^{6} \mathrm{He}$ also does not entertain the traditional notion, further developed in Plato's eschatological myths, that in the afterlife some of the dead are being punished for unjust acts and others rewarded for just acts done during their lifetimes. Instead, he mentions as the only afterlife activity conversation with illustrious heroes from the past. Socrates' comment in the second scenario that he looks forward to examining Sisyphus, among others, makes the omission of afterlife punishments (and rewards) even more noticeable. ${ }^{7}$ This omission is furthermore striking since any system of punishment and reward for the dead would have provided support for the encouragement afterwards offered to the jurors that the gods do not neglect the affairs of a good person (4IC8-D3). Also absent is the view, increasingly gaining in popularity and recurring throughout the Platonic corpus, that the dead re-enter the realm of the living, either immediately or after a temporary stay in the underworld. The limited range of afterlife options discussed, which fails to include some commonly accepted beliefs and hardly shares any link with afterlife accounts found elsewhere in Plato, so serves to further sharpen our attention to the specific scenarios that are presented by Socrates. Why does Socrates develop the two high-level alternatives he outlined at the start, the absence of consciousness and migration, in precisely the way he does?

This question is rendered even more pressing by a second problem with the argument, namely that neither scenario entails a state that can be considered (universally) good. The first of the two options compares the state of being dead, defined as the cessation of perception, to the state of dreamless sleep. Socrates' audience will be familiar with the notion that death entails the cessation of all perception: Aristotle may well be referring to current popular opinion when he states that 'it is believed that for the dead person nothing is either good or bad'. ${ }^{8}$ The

\footnotetext{
${ }^{6}$ Hom., Od. II.487-91.
}

7 The mention of Sisyphus draws attention to another salient difference between this scenario in the Apology and Plato's eschatological myths, namely the company one keeps in the hereafter. In the Apology, there is no segregation among the group of afterlife inhabitants (Socrates positively evaluates the prospect of conversing with not only the just among the illustrious dead, but also the notoriously unjust), whereas in the eschatological myths the just are separated from the unjust.

${ }^{8}$ Arist., EN III5A26-7. Epicurus famously included the argument that death is nothing to us, since good and evil lie in perception and death is the absence of perception (Ad Men. I24), into his arsenal of arguments against the fear of death. The fact that Epicurus felt it necessary to spell out this argument and its implications suggests that its prophylactic gist as regards the fear of death was not generally acknowledged. 
association of death with sleep predates Plato and can be found across many sources: Homer shows the god Thanatos operating together with his twin brother Hypnos, ${ }^{9}$ several Presocratic thinkers allude to the affinity between sleep and death, ${ }^{\text {10 }}$ and Xenophon's Cyrus states that 'among all human things there is nothing that is more akin to death than sleep'. ${ }^{\text {II }}$ Although the comparison between death and sleep will be a familiar one, it will come as a shock to the reader that Socrates calls this scenario a 'gain' ( $\kappa \dot{\varepsilon} \rho \delta \circ$; 40DI-2, E2-3) and adduces it to show that death may be something good $\left(40 \mathrm{C}_{5}-6\right)$. An existence that precludes all perception seems diametrically opposed to the kind of life Socrates values, since it lacks the necessary conditions for a life that is good and worth living. After all, central to Socrates' defence was his belief that what makes life worth living is examining himself and others on virtue. This belief led Socrates to reject the option to abandon his philosophical activity and 'lead a silent and quiet life' in exile ( $\left.37 \mathrm{E}_{3}-38 \mathrm{~A} 5\right)$. And, earlier on, Socrates described the aim of his divinely ordained mission as precisely to awaken the city from its slumber (30EI-3IA8). On what grounds should we now value as a good existence the state of inactivity and unconsciousness that the city, in a defensive countermove, is aiming to bring onto Socrates? ${ }^{12}$ The answer offered by Socrates takes us, again, by surprise: to bring home the point that a state of dreamless sleep truly is good, Socrates invokes the Great King of Persia, traditional paragon of happiness, who would, Socrates imagines, be able to list few days and nights more pleasant than a night of dreamless sleep. In the Gorgias, Socrates initially suspends his judgement on whether the Great King is happy or not - 'for I don't know how he stands with regard to education and justice'13 - only to rank him in the dialogue's closing myth among those with the worst kind of souls, covered in scars as a result of their unjust acts. ${ }^{14}$ Even without knowledge of the Gorgias, the Apology's audience can be assumed to realise that Socrates holds a radically different view on happiness from those who believe the Great King to be supremely happy. It should also have become evident from his defence speech that Socrates does not defer, and certainly not unquestioningly, to the (moral) authority of anyone other than the

9 See Hom., Il. I6.454-5, I6.67I-2, I6.682-3. Greek iconography reflects the close ties between Thanatos and Hypnos who collaborate in carrying away the dead; see Vermeule (1979) I48-5I.

${ }^{10}$ Heraclit. B21, B26; Leucipp. A34; Anaxag. A34 (all DK).

"Xen., Cyr. 8.7.21. Cf. Hom. Od. 13.79-80, Hes. fr. 278.6.

${ }^{12}$ It worth observing here Plato's negative attitude towards the state of sleep elsewhere in the corpus at $\mathrm{Lg}$. 808B $3-6$ : 'For by nature, much sleep does not suit either our bodies or souls [...]. Asleep, someone is not

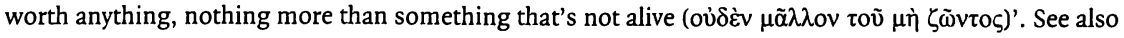
Lg. $747 \mathrm{~B}_{3}-5$.

${ }^{13} \mathrm{Grg} \cdot 470 \mathrm{E}_{4}-9$.

${ }^{14} \mathrm{Grg} .524 \mathrm{E}_{2}-525 \mathrm{~A}_{3}$. Cf. Soph. 230D8-E3. 


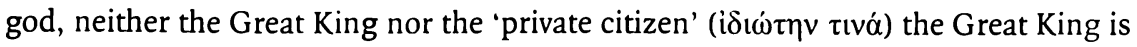
said to surpass (40D8-E2). ${ }^{15}$ The fact that a life of dreamless sleep may seem attractive even to the Great King should thus hold little or no weight for Socrates. However, in our passage Socrates does not question the Great King's assessment in any way, but simply concurs with it, adding that if death were to wrap up the whole of time into a single night, this indeed would be a gain. ${ }^{16}$

There is, of course, a group of people for whom Socrates would argue that an existence characterised by complete inactivity would be better than their current lives. For those whose lives are made miserable because of their injustice, death could be called a 'gain' compared to life. We find Socrates making such an argument at Phd. ${ }_{107} \mathrm{C}_{5}-8$, where he entertains the hypothesis that 'if death were a release from everything, then for the dead who are wicked it would be a godsend to be released from their bodies and at the same time from their wickedness together with their soul'. ${ }^{17}$ Yet while this argument explains how a sleeplike state can be a gain for the unjust, we have no reason to believe that Socrates holds such a negative view of his own life that he would consider the zero-point a gain. Although he does not claim to be just and therefore happy, in his defence speech he does portray himself, in contrast to most other Athenians, as someone committed to justice and self-examination, claiming to have this commitment sanctioned by no one other than the god. The opening scene of, chronologically speaking, the Apology's immediate sequel, the Crito, nicely illustrates Socrates' contentment with his life in a way that draws precisely on the closing themes of the Apology: one of the first questions Socrates asks Crito is why he had not woken him as soon as he had come in rather than let him sleep on. It becomes clear from the ensuing conversation, in which Crito remarks how happy Socrates' life has always appeared to him, that Socrates does not share Crito's belief that it would

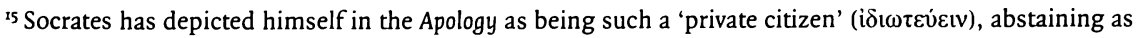
much as possible from political life $(32 \mathrm{AI}-3$ ). (At the same time, of course, Socrates in the Apology redefines what it means to be politically engaged, considering himself to be god's greatest gift to the city; see Schofield (2006) I9-25 for an insightful discussion of the complexities involved in Socrates' selfdefinition in the context of Athenian politics). It is noteworthy that Socrates in the Gorgias myth, after

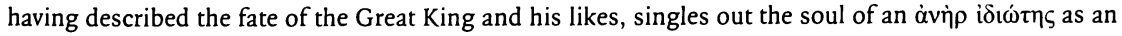
example of a soul sent off to the Isles of the Blest $\left(526 C_{I}-5\right)$. Cf. also Rep. $620 C_{3}-D_{2}$, where Odysseus is

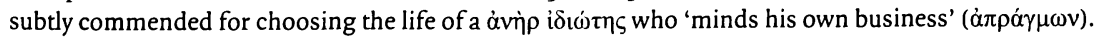

${ }^{16}$ Contrast the view on time at Rep. $608 \mathrm{C}_{5}-7$ where Socrates is speaking of the rewards justice deserves: 'Could anything great come to be in a short time? For the entire period from childhood to old age surely is short compared to the whole of time.'

${ }^{17}$ See $\mathrm{n} .5$ for why this conclusion about death as non-existence would also apply to the condition of absolute non-perception as described in the Apology's first scenario. 
be better to be asleep than to be awake even under his current circumstances. ${ }^{18}$ If the sleep scenario cannot be considered good or even a gain on his current situation for Socrates himself, whose impending death prompted the argument, it fails to show that death is good universally.

The migration scenario also resists an interpretation on which the state of being dead can be understood as universally good, even though the contrast with the first scenario could hardly have been greater. The two key features of this afterlife scenario are that the dead take up residence in a place ruled over by just judges, and that, as a result of their just rule, it will be possible for Socrates indefatigably to continue the activity his current trial interrupted: to investigate everyone he comes across, including the great poets and their epic heroes. Unsurprisingly, Socrates expresses great enthusiasm at this prospect: he asks whether there can be a greater good than to be among all those who have died and states that it will be an 'inconceivable happiness' to examine the countless inhabitants of the underworld. Yet while this scenario evidently involves a good and attractive existence for Socrates, it is not clear how it would entail an equally good existence for those who disagree with him on what a good life consists in, such as his accusers and the jurors who just convicted him. Indeed, Socrates' remark that he would continue to examine people there, just as he did in Athens, 'in order to find out which of them is wise, and which of them thinks he is wise but is not' ( $4 \mathrm{IB}_{5}-7$ ) suggests that, like the Athenians he examined, not all - if any - underworld inhabitants will pass his test. Anyone, then, for whom the first scenario would be a change for the better will find himself no better off than in his current life. This means that also the second scenario does not entail a universally good state and thus fails to support Socrates' conclusion that death is something good tout court. (Admittedly, though not everyone in this scenario will live a good life, the overall conditions in the hereafter would be superior to those currently prevailing in Athens, with divine underworld rulers giving Socrates free reign to engage in socially beneficial philosophical activity.)

These problems with the argument reinforce our earlier concern about the incomplete coverage of afterlife options. Why did Socrates select precisely and only these two scenarios if neither one even supports the claim that death is unconditionally

\footnotetext{
${ }^{18} \mathrm{Crit} .43 \mathrm{BI}-\mathrm{II}$. Note how in the Crito passage, Socrates is presented as enjoying peaceful (خ் $\left.\delta \dot{\varepsilon} \omega \varsigma\right)$ sleep even when awaiting his death sentence in prison (and nonetheless keen to be woken up), whereas in the Apology the Great King is said to be find it hard to find more than a few days and nights better and more pleasant

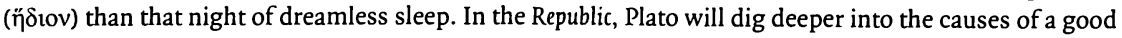
night's sleep and its opposite and argue that the tyrant's life will have been taken completely over by the nightmares that haunted the democratic man only at night as the result of the loss of control by his reasoning part over the desires of his appetitive part; see Rep. 576 $\mathrm{B}_{4}-5,57 \mathrm{IB} 3-\mathrm{D}_{5}$.
} 
good? The argument that Socrates' commitment to his aporia prevented him from dismissing the sleep scenario, the more problematic of the two, out of hand, does not seem to hold, since Socrates apparently did not hesitate to exclude other equally current options. ${ }^{19}$ Some commentators have argued that we are meant to take the sleep scenario as a pseudo-alternative only. By including this option, the argument runs, Socrates has given the jurors who voted for his acquittal an argument that plays into their intuitions for why his impending death should not cause them distress. Whilst Socrates himself should not be taken to endorse the argument he offers, the argument may nonetheless be effective in consoling and encouraging the less philosophically minded jurors. ${ }^{20}$ The appeal to the symbol of happiness, the Great King of Persia, might be taken to aid Socrates' audience in embracing the scenario as good by using a familiar benchmark. On this interpretation, Socrates himself should be taken to either hope or believe, and aiming for the more philosophically minded in his audience to believe, that only the second scenario will come to pass. As I have already argued above, the view that a sleeplike existence is good is indeed hard to fit with the claims that Socrates made during his defence. Yet it seems an unnecessarily complex and puzzling strategy for Socrates to aim to console or encourage the jurors with an argument that he believes is unsound, especially since it would require Socrates to violate the principle he expressed during his defence that he would not say anything merely because it is pleasing to his audience $\left(38 \mathrm{D}_{3}-\mathrm{E}_{5}\right) \cdot{ }^{21}$ Moreover, I question whether his audience would be so much less averse to a state of unconsciousness than to a state of death and hence cheered to learn death may consist in just that. Consider that many of us today view a state of coma with the same, if not more, abhorrence than death. ${ }^{22}$ There is no reason to assume that the ancient Greeks had a different attitude: after all, the association they made between death and sleep, long predating the Apology, did not result in a more optimistic view on death. ${ }^{23}$ The argument that a state

${ }^{19}$ This argument based on Socrates' aporia is made by De Strycker and Slings (1994) 230-I. Cf. Rowe (2007) $98-9$, who argues that the option of the sleep scenario is merely a formal one, since Socrates must clearly be committed to the migration scenario.

${ }^{20}$ See Roochnik (1985) 218 and Stokes (1997) I90-I. Cf. Brickhouse and Smith (2004) I80-I.

${ }^{21}$ It also renders Socrates' analysis of the migration scenario problematic, since there he does not similarly play into common intuitions about what constitutes a good existence; on the contrary, the goodness of that scenario is entirely based on Socratic principles, and not even every 'friendly' juror may be held to look forward to an eternity of incessant Socratic interrogation.

${ }^{22}$ See D. L. Patrick et al. (1995) 9-18 for a study showing that a majority of healthy adults rate coma as worse than or equal to death.

${ }^{23}$ Lucretius later makes the argument that the affinity of death with sleep should make us less concerned about death, going even so far as to claim that death is a condition preferable to sleep, since then for sure we will not wake up from this restful state (DRN 3.912-30). 
of unconsciousness is preferable to death because it would allow for the possibility of 'waking up', i.e. renewed conscious existence, does not do away with the fact that such a state, whilst it lasts, would still be undesirable for the reasons just mentioned. ${ }^{24}$ It is also not the chance to awaken from this sleeplike condition that Socrates highlights when he declares it to be good; rather, he explicitly excludes this possibility of waking up from consideration when claiming that this state would render 'the whole of time' similar to a single day.

\section{II}

These concerns about the argument's soundness prompt the question of why Socrates presents this argument. This question is especially pressing since the argument's conclusion that death is, after all, something good stands in an awkward relationship to the rest of the dialogue. The closing section of the Apology shares this troubling relationship to the rest of the dialogue with Plato's eschatological myths. ${ }^{25}$ When these myths which close the Gorgias, Phaedo and the Republic spell out the benefits justice brings in the hereafter or in one's next life, they jeopardise the moral argument central to these dialogues that justice is its own reward. ${ }^{26}$ Admittedly, there are some striking differences between the Apology's sparse and speculative account and the grand narratives in the later dialogues. Yet Socrates' claim that he has no reason to fear death in the end likewise threatens to deflate the moral conviction he displayed so doggedly throughout his defence, in which he argued as well as showed that fear of negative consequences would not keep him from his commitment to his divine mission or from speaking the truth. ${ }^{27}$ Socrates makes it clear that he believes we should choose the right course of action even if death were an evil: when Socrates praises Achilles for choosing to take the right course of action, he commends Achilles for doing so despite believing that death is an evil and knowing that this will most likely result in his death

${ }^{24}$ For this argument on the state of unconsciousness, see Nagel (1986) 226.

${ }^{25}$ The eschatological myths have been the main focus of the study of Plato's vision of the afterlife. To my knowledge, there are only two instances where the Apology's discussion of the afterlife, in particular the second scenario, is discussed in the context of later eschatological myths: Rowe (2007) 97-109 reads the Apology's second scenario in the context of the Phaedo's closing myth and argues that the Apology already contains in nuce the more colourful eschatology of the Phaedo; Brickhouse and Smith (1994) 20I-I2 develop the analogy between the second scenario and the eschatological myth in the Gorgias.

${ }^{26} \mathrm{Cf}$. Sedley (2009) $5 \mathrm{I}$, who suggests that this may explain the relative neglect of Plato's myths in interpreting the dialogues of which they are a part.

${ }^{27}$ Socrates makes this point no fewer than three times $\left(28 \mathrm{~B}_{3}-29 \mathrm{~A}_{2}, 30 \mathrm{~B}_{7}-\mathrm{C}_{2}, 38 \mathrm{E}_{2}-5\right)$. 
$\left(28 \mathrm{CI}-\mathrm{D}_{4}\right) .{ }^{28}$ The critical reader may therefore point out that the dialogue would have conveyed a more convincing message if the question on death's nature had been left open. As it is, Socrates' conviction that it is always better to act justly, regardless of any hardships that may result, seems weakened when we learn by the end of the dialogue that the consequences of his actions turn out to be a great blessing to him. While I do not wish to claim that the purpose of the Apology is to portray a Socrates who heroically defies hardships, Socrates' final argument that death is not an evil after all seems at best a distraction from his earlier claims about the value of living a just life. ${ }^{29}$

Moreover, in contrast to the later afterlife accounts, the argument in the Apology does not mention any rewards for justice, but instead argues for the (universally) good nature of death. A conclusion that death is a blessing for just and unjust alike makes this coda to his defence speech even less palatable. For why would Socrates want to argue for the claim that death is something good without further qualification? If his aim is to console his audience with his death, he just as easily could have used the evidence from his divine sign that all will turn out well for him as a springboard for further reflection on his own death. Or, if his aim is to convince the jurors and ultimately his wider audience not be deterred by his death from taking up philosophy, he could have elaborated what the silence of the divine sign means not only for himself, but for any just person. In these cases, Socrates only would have needed to give a scenario on which death would turn out to be good for himself or any just person. Such a scenario would have illustrated why his divine sign was rightly silent and would also have supported the claim he makes immediately following our argument that 'no harm can come to a just person either in life or death' (4IC8-D2). As possible ways in which Socrates could then have envisaged death turning out well for him and people like him, he could have referred to traditional accounts about how people who enjoy the special favour of the gods are sent to the Isles of the Blest, if he wanted to stay close to common beliefs, or, more in tune with the Laws in the Crito, expressed confidence

\footnotetext{
${ }^{28}$ Socrates' belief expressed at $30 \mathrm{C}_{7}-\mathrm{D} 6$ that suffering death is not a greater harm than acting unjustly (cf. $38 \mathrm{E}_{2}-39 \mathrm{AI}$ ) is in this regard more ambiguous, since it does not commit Socrates to the claim that death is thereby also an actual harm. At $29 \mathrm{~A}_{2}-\mathrm{C}_{1}$, Socrates offers a prudential reason why one should not be concerned about death when faced with the choice between a right and a wrong action: since we know that acting unjustly is bad, but do not know whether death is an evil or not (it may, for all we know, be the greatest good), it would be foolish to take the consequence of death into consideration when making moral decisions.

${ }^{29}$ Yet it is worth noting that Socrates draws a parallel between himself and the Greek heroes who died in Troy, in particular Achilles, who preferred death above disgrace (28CI-D4). For a discussion of this comparison, see Hobbs (2000) 179-86.
} 
in a warm reception by the rulers in Hades. ${ }^{30}$ Such accounts would highlight even more clearly than the migration scenario that the gods care for the just by rewarding them for their justice with afterlife bliss..$^{31}$ Admittedly, for Socrates to claim such special divine treatment would have been rather provocative in light of his conviction for impiety, but hardly more so than his defence had been. This approach, furthermore, would have enabled him to discard any alternatives in which death would not be good for him (or any just person), such as the sleep scenario, as in conflict with the evidence from divine sign. In that way, Socrates would have added meat to his divinely sanctioned belief that he will be well off in the end, after alone having served god in the right way, without violating his earlier self-professed ignorance about the nature of death.

\section{III}

Let us take stock. Besides the argument's problematic relationship to the rest of the dialogue, we identified two major flaws in the argument itself: (I) the scenarios Socrates presents are not exhaustive, and (2) only one scenario can be judged good by Socratic standards, while Socrates claims both scenarios to be good. The blatant failure of the two scenarios to support the conclusion that death is something good makes us wonder why Socrates introduces them here. To make sense of this, I propose that we turn to the preceding sections of the Apology, where we see the conflict between a dormant existence and an examined life develop as an important theme that underlies the very conflict between Athens and Socrates. First, in his defence speech, Socrates justifies his critical and active way of life whilst showing how he tried to steer Athens away from the undisturbed life it desired for itself. Later, in his sentencing speech, Socrates makes it clear with his counterproposal to the death penalty, free meals in the Prytaneum, that the only life he considers worth living is a life of continuous (self)examination, thus rejecting the option more amenable to the jury of a quiet life in exile. Lastly, the votes of the jury to convict Socrates and to impose the death penalty confirm that they are firmly committed to an undisturbed life, free from interference

${ }^{3 \circ}$ Crit. 54 B3-D2.

${ }^{31}$ Rowe (1997) 97-109 and Brickhouse and Smith (2004) 20I-12 argue that the migration scenario in the Apology already contains the core elements of the eschatological closing myths in the Phaedo and Gorgias respectively. I would argue, however, that the Apology differs from both these myths on a number of crucial points, of which the most striking is the absence of a universal judgement of all afterlife inhabitants, followed by the allocation of the appropriate rewards and punishments. 
by Socrates. This theme of the conflict between the lives pursued by Socrates and Athens we now see continued in the constructive dilemma, with distinctive overtones of its earlier discussion. The first horn of the dilemma, the sleep scenario, depicts the passive life Athens desires. Commended for making all of time seem nothing more than a single night (40E3-4), it recalls Socrates' description of Athens's plight, in which he warned the city that it could easily pass the rest of its life in slumber unless the god would send a successor for him (3IA5-8). The other horn, the migration scenario, offers us the life Socrates desires. When Socrates describes how he will spend his afterlife testing and examining people to see who is wise and who, thinking to be wise, is not $\left(4 \mathrm{IB}_{5}-7\right)$, he echoes his earlier account of how he went about Athens to examine anyone whom he believed to be wise $\left(23 \mathrm{~B}_{4}-6\right)$.

But how are we to take the reappearance of these two modes of life in Socrates' concluding reflections on the nature of death? I propose that Socrates uses the argument on death to challenge his audience, within the confines imposed by a monologue, to critically examine and evaluate these two ways of life. Reflecting on what existence each scenario entails, just as we have been doing, should result in the understanding that the scenarios are in conflict with each other and can be judged good only by opposing standards. Socrates thus prompts the jurors once again to consider the question whether it will consider attractive a dormant existence, which precludes even the very possibility to reflect on what is truly valuable, or whether it will side with Socrates in only valuing an existence that enables uninterrupted examination and reflection. The challenge to the audience to identify that the argument offers competing alternatives, only one of which represents an existence that Socrates considers worth living, is signalled by a number of rhetorical strategies that highlight the ironic tendency of this passage. ${ }^{32}$ First, with regard to the migration scenario, Socrates emphatically and

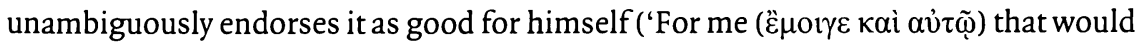
be a marvellous way to spend my time there'; $4 \mathrm{I} \mathrm{BI}$ ), declaring that it will bring him

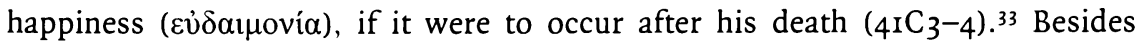

\footnotetext{
${ }^{32}$ David Sedley pointed out to me that Socrates' irony may well be entirely lost on these jurors and aimed instead at the readers of the Apology. Whilst I agree that it is very likely that this irony would have escaped the historical jurors in Socrates' trial, I would nonetheless argue that it is through the identification with these jurors and the context they are in that the constructive dilemma should be interpreted.

${ }^{33}$ The term घuobauovi $\alpha$ and its cognates are used sparsely in the Apology (the only occurrence outside the migration scenario besides $25 \mathrm{~B} 7-\mathrm{CI}_{\mathrm{I}}$, where it is used ironically, is $36 \mathrm{D} 9-\mathrm{Io}$, where Socrates states that he makes the Athenians happy, and not just makes them believe they are happy); its use here, and immediately afterwards at $4 \mathrm{IC}_{5}-6$, brings out the juxtaposition between (true) happiness according to

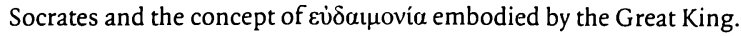


emphasising the happiness he believes this scenario will give him, Socrates also solicits his audience's agreement: through four (semi-)rhetorical questions he invites the jurors to share in his own positive appraisal of this prospect $\left(4 \mathrm{OE}_{3}-7,4 \mathrm{OE} 7-4 \mathrm{IA6}\right.$, 4IA6-7, 4IB7-C4). ${ }^{34}$ The sleep scenario, by contrast, lacks the emphatic approval by Socrates himself and any attempt to get his audience to agree with him, but is instead given as its main advocate that problematic paragon of happiness, the Great King. Socrates' endorsement of the Great King's position that a dreamless night's sleep surpasses all other days and night of his life should put anyone on his guard who, either in the course of Socrates' defence or before, has come to understand what Socrates' view on the good life consists in. Because anyone familiar with Socrates' view on the good life will realise that his endorsement of the Great King's assessment means not that he believes that even the best of lives is outdone by a single night of dreamless sleep, but rather that the happiest kind of life as popularly conceived is of no more value than what amounts to its very cessation. This ironic concordance between Socrates and the Great King is borne out in the subtle use of the cognates

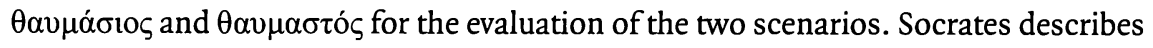
the 'gain' of a sleeplike existence as follows: 'If it is indeed a complete absence of perception (...) death would be a remarkable ( $\theta \alpha v \mu \alpha$ ó parallel qualification in Socrates' discussion of the migration scenario, where he uses

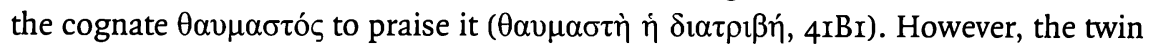

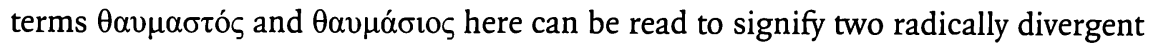
evaluations: for whereas $\theta \alpha v \mu \alpha \sigma \tau o ́ \varsigma$ should be taken to reflect Socrates' own positive

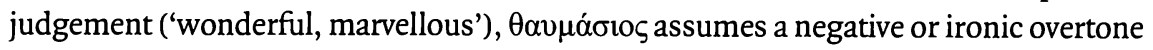
('strange') in that it surely seems a remarkable kind of gain for the 'best' kind of life to benefit from coming, practically speaking, to an end. ${ }^{35}$

On this reading, then, Socrates does not set out to convey his speculation about death, in particular why he would believe it to be unconditionally and universally good, or even why he has no reason to fear it. Rather, through offering contrasting afterlife conditions, he intends to foster further reflection by his audience on what makes life

\footnotetext{
${ }^{34}$ Note also how the contrastive use of the personal pronouns ( $\left.\tau 1 \zeta\right)$ vं $\mu \tilde{\omega} v$ (in Socrates' question at 4IA6-7) and $\dot{\varepsilon} \gamma \omega$ and $\ddot{\varepsilon} \mu o เ \gamma \varepsilon$ (in his answer, 4IA7-BI) brings out Socrates' aim to align these jurors with his own beliefs which informed his defence.

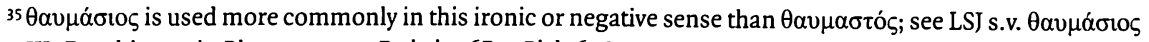
III. For this use in Plato see e.g., Euthphr. 6B5, Phd. 60B4, Smp. 177B6, Euthd. 299E6, Prot. 325B3, 36rB6, Grg. 496A6, as well as the direct addresses frequently used by Plato $\theta \alpha v \mu \alpha \dot{\sigma} \varepsilon \varepsilon$ and $\theta \alpha v \mu \alpha ́ \sigma t o t$. Note, however, the ironic use of $\theta \alpha u \mu \alpha \sigma \tau$ có at Tht. I54B6.
} 
good and worth living. ${ }^{36}$ (In this way, the Apology offers us perhaps the first instance where an afterlife account is introduced in Plato to prompt reflection on what life to live. The clearest parallel is of course provided by the Republic's myth of Er, which locates a choice of lives in the afterlife itself.) Socrates' focus on what makes life worth living is made especially apparent when he breaks through the veil of afterlife speculation in describing how he would enjoy continuing his philosophical activity in the hereafter: Socrates asks the jury members how much they would be willing to give to converse with Orpheus, Musaeus, Hesiod and Homer, and responds that he in any

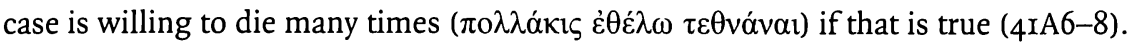
Here Socrates directly references the claim he made at the heart of his defence that he will continue to act in the way he has even if he must face death many times (òv $\delta$ ' $\varepsilon \dot{i}$

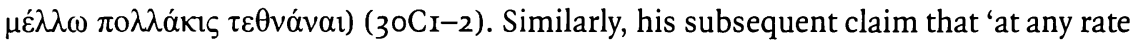
they do not put one to death for [examining the residents of the underworld]' (4IC45) shows that Socrates has moved beyond exploring the nature of death, since this claim too rests on the assumption that death may well be something bad..

One may object that this dilemma, which Socrates is imposing on any perceptive jurors, is no longer relevant at this point in the dialogue: after all, the jurors already cast their votes on the charges against Socrates. Yet while the jury as a whole has indeed has made its decision regarding Socrates' fate and thereby the life they envision for the city, the group of jurors Socrates is currently addressing can still be taken to face yet another choice. ${ }^{37}$ From their way of voting they can be assumed to hold, at a minimum, a charitable stance towards Socrates and his mission, with some of them possibly already attracted to the Socratic programme. These jurors now find themselves in a precarious position - and by extension the same can be said of the dialogue's initial readership, many of whom will be able to recall the events surrounding Socrates' trial. Having seen Socrates convicted and sentenced to death

${ }^{36}$ To my knowledge, the only commentator who argues that the constructive dilemma should be read at a deeper level where it intends to encourage further reflection along protreptic lines is Roochnik (1985) 2I6-2I. Roochnik distinguishes two levels in the argument, aimed at two different types of audience: a non-critical audience that is expected to read the argument at face value and for whom it offers consolation and comfort, and an attentive audience for whom the message of the argument is that 'only if death permits the continuation of philosophy can it be counted a gain' (218). Roochnik's reading, however, differs from my reading in a number of important respects: first, I argue that even the surface level reading poses significant interpretative problems (such that I take them to be cues to the deeper reading); secondly, Roochnik does not unpack the meaning of the juxtaposition between the two scenarios, but focuses mainly on the value of the afterlife scenario.

${ }^{37}$ David Johnson drew my attention to the importance of the position the jurors find themselves in for our understanding of this passage. 
may well cause them to renounce any sympathy for the Socratic enterprise, rather than to follow through on the call to self-examination that Socrates made throughout his defence speech. Socrates himself had already expressed his awareness of the risks involved in following his example when stating that 'there is no danger of its [i.e., trials such as the current one] stopping with me' $(28 \mathrm{BI}-2) . .^{8}$ In the constructive dilemma, then, Socrates deals with the implications of his trial for the 'friendly' jurors by engaging them in further reflection on what makes life worth living. This objective also explains the remarkably interactive character of his address of these jurors that we noted earlier. By contrast, in the immediately preceding speech to the jurors who convicted him, Socrates merely described the condition these jurors condemned themselves too - 'a state of wickedness and injustice' - without soliciting any response or agreement (39A6-B8); this group by their votes have already taken their definitive position on the Socratic enterprise and all that was left for Socrates was to spell out the condition they condemned themselves to when they convicted him.

If we take the constructive dilemma to address the choice faced by the jurors, we see a clearer line of argument emerge in the dialogue's closing passage. Take Socrates' statement immediately following our argument:

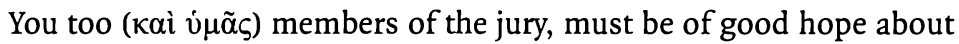
death and bear this one truth in mind, that a good person cannot be harmed either in life or in death, and that the gods do not neglect his affairs. (4IC8-D2)

When stating that the jurors too have reason to be hopeful about death, since no harm can come to any good person, Socrates seems to refer back to his earlier argument based on the silence of his divine sign, from which he concluded that his own death might well not be bad for him. ${ }^{39}$ Sandwiched in between these reflections on the silence of his divine sign and Socrates' encouragement of the jurors we are given the constructive dilemma. If we take the constructive dilemma to show that death is good without further qualification, the subsequent reassurance of the jurors on death appears altogether superfluous. But if we take the constructive dilemma to convey a

${ }^{38}$ This is an interesting remark in light of the fact that, as far as we know, no similar processes were held during the first few decades of the fourth century BCE; see Fahr (1969) 182. We could take this as an indication for dating the Apology closer to rather than further removed in time from the date of Socrates' trial.

${ }^{39}$ See also Socrates' belief expressed during his defence speech that neither Meletus nor Anytus would be able to harm him, since it would not be allowed $(\theta \varepsilon \mu 1 \tau$ ív) for a better man to get harmed by a worse (30C9-D2). 
protreptic message by prompting the jurors to live an examined life, this encouragement no longer appears redundant. Rather, such encouragement seems especially appropriate after the call to join Socrates in a pursuit that anyone who has just witnessed his conviction has reason to be apprehensive about.

The suggested interpretation of Socrates' argument on death also deals with any concerns raised by the dialogue's closing statement that 'no one knows who of us goes to the better lot other than the god' $\left(42 \mathrm{~A}_{3}-5\right)$. This statement, too, would come as a surprise so shortly after a conclusive argument about the good nature of death. Commentators, following Cicero, have almost universally taken Socrates' final phrase to indicate a reversal to his disavowal of knowledge about death in his defence speech..$^{\circ}$ But on our reading of the argument, Socrates will have maintained his aporetic position on death all along. This means not only that his view on death in the dialogue's closing passage is consistent with that in the rest of the dialogue, but, more importantly, that even after his conviction he has shown his steadfast commitment to the belief that the only consideration in choosing what action to take and - and life to live - is whether it is right. ${ }^{41}$

Such a protreptic reading of Socrates' closing speech fits in with an argument already made elsewhere that Socrates in his defence speech not only undertakes to show that he is innocent of the charges brought against him, but also aims to educate his immediate audience, the jurors..$^{42}$ Unlike the forensic motive, the didactic motive of his speech has not come to a conclusion with his sentencing. Rather, it requires that Socrates show the jurors who voted in his favour that his beliefs and choices hold up even when the death penalty is the result, and that he encourage them to follow through on the initial approval of the Socratic enterprise expressed in their verdicts. So while Socrates' final address in the case of a mere defence speech would have been at best redundant (his conviction is now a fact) and stretching the dialogue's dramatic limits (the delivery of such a speech was not customary and perhaps not even possible in the Athenian courthouse), with it Socrates has now also brought his didactic project to a conclusion.

Can we then not ascribe any positive view on death to Socrates? We need not go that far. The closing of the Apology shows us a Socrates who is optimistic, though not

${ }^{40} \mathrm{C}$ icero, Tusc. Disp. I.99. For Socrates' aporetic positon on the nature of death, see 37B5-7; cf. 29A5-B2.

${ }^{41}$ Only just before, in his speech to the jurors who convicted him, Socrates confirmed that his conviction has not caused him to change his mind on whether he defended himself in the right way, since he (still) prefers death to an alternative scenario where he would have given a defence aimed at avoiding sentencing (38D6-39A6, echoing 28D5-29A2).

${ }^{42}$ See Ober (1999) 178 and $168-9$ n. 27. 
certain, about a good outcome overall, and possibly even about death itself. Yet the grounds for his optimism regarding death are informed not by rational argumentation such as given in the constructive dilemma, but by his belief in divine care for human beings, as is demonstrated in his reasoning about the silence of his divine sign and his reassurance of the jurors regarding the gods' care for any good person..$^{43}$ The scenarios offered in the constructive dilemma, as I have argued, find their basis in the conflict between the two modes of life played out in the dialogue, not in Socrates' speculation about the afterlife.

ALICE VAN HARTEN GHENT UNIVERSITY

${ }^{43}$ Several passages in Plato's so-called 'Socratic dialogues' show Socrates' belief in good and wise gods as one of his few positive intuitions and crucial to a proper understanding of the Socratic enterprise. The Apology focuses on Socrates' belief that the gods are supremely wise and that human wisdom is worth little or nothing (most prominently at $23 \mathrm{~A}_{5}-7$; for references to the god's goodness, see $30 \mathrm{D}_{6-3 \mathrm{IB}}$, where Socrates explains how his beneficial service to the city is divinely ordained, and $40 \mathrm{~A}_{2}-\mathrm{C}_{4}$, Socrates' discussion of the silence of his divine sign,); the Euthyphro provides the locus classicus for Socrates' belief that the gods are good and the source of all good things for men (prominently highlighted later on in a passage reminiscent of the 'Socratic dialogues', Rep. $379 \mathrm{BI}-\mathrm{C}_{7}$ ). 


\section{WORKS CITED}

Armleder, P. (1966), 'Death in Plato's Apologia', CB 42, 46.

Brickhouse, T. C., and Smith, N. D. (I990) Socrates on trial, Oxford.

- (1994) Plato's Socrates, Oxford.

(2004) Plato and the trial of Socrates, London.

Burnet, J. (1924) Plato's Euthyphro, Apology of Socrates and Crito, Oxford.

De Strycker, E., Slings, S. R. (1994) Plato's Apology of Socrates [Apology], edited and completed from the papers of the late E. De Strycker, Leiden.

Fahr, W. (1969) Theous nomizein, New York.

Hobbs, A. (2000) Plato and the hero: courage, manliness, and the impersonal good, Cambridge.

Patrick, D. L., et al. (1995) 'Measuring preferences for health states worse than death', Medical Decision Making I4.I, 9-18.

McPherran, M. L. (1996) The religion of Socrates, University Park, Pa.

Nagel, T. (I986) The view from nowhere, Oxford.

Ober, J. (1999) Political dissent in democratic Athens, Princeton, NJ.

Roochnik, D.L. (1985) 'Apology 40c4-4re7: Is death really a gain?', CJ 80, 212-20.

Rowe, C.J. (2007) Plato and the art of philosophical writing, Cambridge.

Rudebusch, G. (1999) Socrates, pleasure, and value, Oxford.

Schofield, M. (2006) Plato: political philosophy, Oxford.

Sedley, D. N. (2009) 'Myth, politics and punishment in the Gorgias', in C. Partenie (ed.), Plato's myths, Cambridge, $5^{\mathrm{I}-76}$.

Stokes, M. C. (1997) Plato: Apology, Warminster.

Vermeule, E. (1979) Aspects of death in early Greek art and poetry, Berkeley, Calif.

Warren, J. (2004) Facing death: Epicurus and his critics, Oxford. 